\title{
THE ROLE OF CREATIVITY IN THE PROFESSIONAL DEVELOPMENT OF FUTURE FOOD INDUSTRY ENGINEERS-TEACHERS
}

\section{РОЛЬ ТВОРЧОСТІ В ПРОФЕСІЙНОМУ РОЗВИТКУ МАЙБУТНІХ ІНЖЕНЕРІВ-ПЕДАГОГІВ ХАРЧОВОЇ ГАЛУЗІ}

\author{
Olga KURILO, \\ postgraduate student \\ Ольга кУРИЛо, \\ аспірантка \\ https://orcid.org/0000-0002-8344-869X \\ olgakurilo_1990@ukr.net \\ Berdiansk State Pedagogical \\ University \\ $\triangle 4$ Schmidta St., \\ Berdiansk, Zaporizhzhia region, \\ 71100 \\ Бердянський державний \\ педагогічний університет \\ $\triangle$ вул. Шмідта, 4 \\ м. Бердянськ, Запорізька обл., \\ 71100 \\ Dinal manuscript received: October 01, 2019 \\ Revised manuscript accepted: December 17, 2019
}

\begin{abstract}
The article is devoted to theoretical substantiation of creative component of professional development of food industry engineers-teachers. Modern socio-economic conditions open up new directions for the development, creation and implementation of promising models for the training of competent specialists, namely engineers-teachers. Future engineers-teachers should combine professional knowledge and skills, with the skill to carry out training of specialists capable of creative work, professional self-development, improvement, which can adapt in time to changing market conditions. Among these, it is worth noting the engineers-teachers of the food industry, the training of which focuses on mastering a holistic system of professional knowledge, skills, experience in creative professional activities, building willingness to solve creative production problems, manifesting creativity, intellectual, spiritual and moral abilities. By its nature, creativity requires originality, the ability to abandon stereotypes of activity, knowledge, although without such stereotypes as the base, it is impossible. Therefore, a professional person should, on the one hand, have a set of standardized knowledge, skills, and on the other - the ability to abandon them in search of other knowledge and activities that are more appropriate for the situation. At this moment, a creative transformation by a person of reality takes place, its further development. Future food industry engineers-teachers need motivation for productive, creative professional activity. Creativity becomes a significant tool for students' educational, cognitive and research activities.
\end{abstract}

Key words: creativity, creative activity, engineer-teacher, engineer-teacher of food industry, professional competence.

Вступ. Унаслідок інтенсивних економічних змін, пов'язаних із переорієнтацією на ринкові відносини, виходом на світовий ринок і прискореним розвитком певних галузей економіки в Україні, зростає 
потреба у кваліфікованих кадрах нового типу, які вміють ефективно й творчо розв'язувати професійні завдання. Саме активізація творчого потенціалу людських ресурсів прискорює культурно-економічний прогрес країни та підвищує рівень життя її громадян.

Харчова промисловість завжди вважалася для України пріоритетною і стратегічно важливою галуззю. Доступність харчових продуктів, їх якість та екологічність впливають на рівень продовольчої безпеки держави, виступають індикаторами її соціальної стабільності. Крім того, наша країна має найбільш сприятливий природний, людський, геополітичний i ресурсний потенціал для розвитку харчової промисловості, раціональне використання якого може забезпечити провідне місце на світовому й регіональному продовольчих ринках.

Система вищої професійної освіти $€$ одним з основних чинників забезпечення стійкого зростання і розвитку економіки країни. У законах України "Про освіту" (2017р.), “Про професійно-технічну освіту” (1998р.), Національній стратегії розвитку освіти в Україні до 2021 року (2014р.) зазначається, що саме на педагогів професійного навчання нині покладається важлива місія підготовки, кваліфікованих, конкурентоспроможних фахівців, які відповідають вимогам технологічного розвитку галузей економіки, а також мають високий рівень творчої ініціативи. Педагоги такої формації потребують відповідної підготовки спрямованої на оволодіння цілісною системою професійних знань, умінь, навичок, досвідом творчої професійної діяльності, формування готовності до вирішення виробничих творчих завдань, інтелектуальних і духовно-моральних здібностей та професійний розвиток.

Перераховані вище положення спрямовують працівників освіти і науковців на пошуки нових шляхів реалізації освітніх, виховних і розвивальних цілей закладів вищої освіти. Нині існують напрацювання педагогічної науки щодо підготовки майбутнього педагога до професійної діяльності (В. Андрущенко, Ю. Бабанський, Р.Горбатюк, Р. Гуревич, І. Зязюн, Н. Кузьміна, Н. Мойсеюк, І. Підласий, С. Сисоєва, В Сластьонін та ін.) та їі вдосконалення (О. Мороз, О. Пєхота, Т. Сущенко та ін.); становлення майбутнього фахівця у ЗВО (К. Абульханова-Славська, Б. Ананьєв, Л. Божович, Л. Бодальов, О.Галус, А. Деркач, Е. Зеєр, Є. Клімов, А. Кудрявцев, Н. Кузьміна, А. Маркова, Л. Мітіна, І. Мельничук, В. Орлов, О. Пєхота, В. Поліщук, Л. Романишина та ін.); психологопедагогічні концепції підготовки майбутнього педагога до педагогічної творчості (В. Андреєв, Н. Кічук, С. Сисоєва, Т. Сущенко та ін.); психологічні теорії творчої особистості та її розвитку (Б. Богоявленська, О. Лук, В. Моляко, Я.Пономарьов та ін.). Однак на сьогодні залишається недостатньо вивченою роль творчості в професійному розвитку майбутніх інженерів-педагогів харчової галузі.

Мета дослідження полягає в теоретичному обґрунтуванні творчого складника професійного розвитку інженерів-педагогів харчової галузі.

Відповідно до мети визначено такі завдання: дослідити сутність творчості на фрілософському та психолого-педагогічному рівні; встановити 
зв'язок між творчою особистістю інженера-педагога та його майбутньою професійною діяльністю; виявити очікуванні результати підготовки майбутніх інженерів-педагогів харчової галузі, спрямованих на творчу професійну діяльність. Для досягнення мети, розв'язання завдань використано сукупність взаємопов'язаних теоретичних методів дослідження: аналіз освітньо-професійної програми - для виявлення наявності творчих орієнтирів у профілях підготовки майбутніх інженерівпедагогів харчової галузі; узагальнення і систематизація науковотеоретичних положень - для уточнення сутності основних понять, істотних для розробки проблеми професійного розвитку інженерівпедагогів харчової галузі на основі творчого підходу.

Результати та дискусії. Нині істинним напрямком прогресу суспільства загалом та пріоритетною направленістю саморозвитку кожного стало стимулювання становлення творчих процесів. Суспільство та кожен її член при цьому - суб'єкт творчої діяльності, наслідком якої є формування середовища, перебудова природи, розвиток цивілізації. Тобто творчість - це складне, суспільно організоване явище, від якого залежить життя людства, та умовний термін для позначення психічного акту, що виражається у втіленні, відтворенні або комбінації даних нашої свідомості в новій формі у сфері абстрактного мислення, художньої та практичної діяльності (Батюшков, 1901). Доречним з цього приводу $є$ вислів В. Сухомлинського: "Творчість - це не сума знань, а особлива спрямованість інтелекту, особливий зв'язок між інтелектуальним життям особистості і проявом її сил в активній діяльності".

У фрілософрській та психолого-педагогічній науковій літературі творчість розглядається по-різному: як "створення чогось нового" (Батюшков, 1901); як "вища форма активності і самостійності в діяльності людини та суспільства" [філософи]; як "продуктивна людська діяльність" (Гончаренко, 1997), як "сукупність особистісних якостей, що визначають і зумовлюють відношення людини до світу і самої себе" (Даниленко, 1996), як "необхідна для повноцінного життя людини форма ії існування" (Бодалев, 1995), як “процес творчої діяльності, продукт творчої діяльності, здатність до творчої діяльності, різні типи мислення або розумової діяльності, різноманітні утворення в структурі особистості, фрактори навколишнього середовища, що зумовлюють і впливають на результат творчої діяльності" (Обухова, 1990); як "створення чогось нового в ситуації, коли проблема - подразник викликає створення домінанти, навколо якої концентрується необхідний для рішення запас минулого досвіду" (Бехтерев, 1910). Деякі науковці зазначають, що "творчість не в усіх випадках обов'язково $є$ створенням чогось нового, вона може мати форми рекомбінації певних існуючих і відомих елементів або бути руйнівною відносно цих елементів" (Поташник, 1988).

Отже, творчість є дуальною категорією, яка інтегрує два підходи до ії̈ вивчення: процесуальний - дослідження фраз, станів, стадій та результатів перетворення предмета творчості та особистісний дослідження суб'єкта творчої діяльності, його потреб, мотивів, знань, 
умінь, навичок, властивостей, самосвідомості, емоцій, почуттів.

Існує певна закономірність - творчість як людська діяльність вищого рівня в процесі пізнання і перетворення навколишнього природного та соціального світу змінює й саму людину, тобто способи ії мислення, особистісні якості, формуючи творчу особистість. Творчість містить у собі елемент нового, передбачає оригінальну діяльність, здатність до рішення проблемних ситуацій, продуктивну уяву в сполученні 3 критичним відношенням до досягнутих результатів. Діапазон творчості охоплює дії від нестандартного рішення простого завдання до реалізації унікальних потенцій індивіда в професійній діяльності (Біла, 2014).

3 іншого боку, творчість як діяльність спрямована на вирішення завдань, для яких характерна відсутність у предметній області (або тільки у суб'єкта) не тільки способу розв'язання, але, головне, предметноспецифічних знань, необхідних для його розробки - постулатів, аксіом, теорем, законів і таке інше. І. Калошина виокремлює такі ознаки творчої діяльності: творча діяльність спрямована на розв'язування задач, для яких характерна відсутність у предметній галузі (або тільки у суб'єкта) необхідних для ії розробки постулатів, теорем, законів та інших положень; творча діяльність пов'язана зі створенням суб'єктом на усвідомлюваному чи неусвідомлюваному рівнях нових для нього знань як орієнтовної основи для наступної розробки способу розв'язування задачі; творча діяльність характеризується для суб'єкта можливістю розробки нових знань і на їх основі способу розв'язування задачі (Калошина, 1983).

А. Маслоу першим наголосив, що творчість $\epsilon$ найбільш універсальною функцією людини, яка призводить до всіх форм самовираження та $€$ важливою складовою процесу самоактуалізації. За визначенням Дж. Рензуллі, творчість - це особливість поведінки особистості, що виражається в оригінальних способах отримання продукту, досягненні розв'язання проблеми, у нових підходах до проблеми з різних точок зору (Renzulli J., Reis S., \& Smith L., 1981).

Сучасні науковці все частіше пов'язують активність особистості 3 реалізацією іï потенційних можливостей. Так, Л. Білієнко розглядає творчість як діяльність особистості, що створює матеріальні і духовні цінності, котрі мають не тільки особистісне значення, а й соціальне. Разом з тим це досягнення результату, процес, в якому особистість стверджує і реалізує свої потенційні сили і здібності, розвивається і самореалізується (Білієнко, 1994). Т. Білобровко стверджує, що творчість - це єдиний, цілісний процес усвідомленого, цілеспрямованого та вільного розвитку сутнісних сил індивіда, реалізації його можливостей у різноманітній життєдіяльності особистості (Білобровко, 1996).

Природна здатність до творчості $€$ неоднаковою в різних людей. Саме тому можна спостерігати такі парадоксальні на перший погляд явища, коли одні вносять творче начало в найбільш рутинну працю, а інші - рутинно здійснюють творчу за своїм характером діяльність. Найважливішим показником вияву творчого потенціалу особи і $є$ те нове, що з'являється не тільки в результаті праці, пізнавальної діяльності, а й у 
ії процесі, підходах, ставленні, засобах, методах тощо. У всій розмаїтості нового певною мірою виявляється творчий потенціал особи. Дійсне багатство, різнобічність творчого потенціалу й активності особи повністю залежать від її творчих нововведень.

Особа не завжди повною мірою осмислює потребу в творчості, усвідомлює свої творчі потенції, а також шляхи і способи їх реалізації. Її творчий потенціал може розкритися за надзвичайних обставин, коли відбуваються мобілізація сил людини і виявлення прихованих резервів, які реалізуються у творчості, вчинку, матеріальній і духовній діяльності. По суті, будь-яка творчість - це крок у невідоме, коли поряд з відкриттям, створенням нового в зовнішньому для людини світі не менше (а в деяких аспектах і більше) значення має виявлення нового в собі (власних можливостей) і з'ясування нового у своєму ціннісному ставленні до дійсності (Кривильова, 2008).

Так, ринок праці, що інтенсивно фрормується, входження України в цивілізоване світове співтовариство обумовлюють зростання вимог до рівня кваліфікації та особистості інженера-педагога, який здійснює підготовку робітничого потенціалу країни закладах професійно-технічної освіти. Особливої важливості питання особистості інженера-педагога набуває через появу суперечностей між стрімкими темпами технічного прогресу та інертністю системи професійно-технічної освіти в підготовці кадрів, здатних підняти вітчизняне виробництво до світового рівня.

Розв'язанню цього протиріччя має сприяти підготовка ініціативних, творчих інженерів-педагогів, здатних орієнтувати свою діяльність залежно від динамічних потреб ринку праці та забезпечувати ефективні напрямки професійної підготовки. Тому інженерно-педагогічна освіта має здійснювати формування творчої особистості, створювати умови для найповнішого розкриття її здібностей та потенціалу, задоволення освітніх потреб (Романчук, 2006).

Нині заклади професійно-технічної освіти, харчове виробництво та сфрера обслуговування потребують висококваліфікованих педагогічних працівників і робітників, які здатні до ефективної професійної роботи за фахом, володіють здатністю вирішувати проблеми творчо, в тому числі професійні, що виникають у реальних ситуаціях діяльності 3 використанням знань, життєвого і професійного досвіду, відчувають необхідність у постійному професійному зростанні (Герлянд, 2010). Цілком очевидно, що вказані якості повинні ґрунтуватися на професійній компетентності майбутніх фахівців, яка передбачає наявність особистого творчого потенціалу, глибокого розуміння виробничо-педагогічних явищ.

Визначення результатів навчання у вигляді цільової, базової функції системи професійної освіти означає перехід до нової моделі підготовки, коли акцент зі змісту (що викладають) переноситься на результат (якими компетенціями оволодіє майбутній фахівець, що він буде знати і готовий робити) (Дубова, Харитонова, 2018).

Для успішного вирішення професійно орієнтованих задач майбутній інженер-педагог у галузі харчових технологій повинен уміти аналізувати 
реальну ситуацію, знаходити оптимальні шляхи її поліпшення, пропонувати найбільш ефективні рішення проблем, що виникають, володіти навичками роботи з різними джерелами інформації. При цьому найважливішим напрямом формування професійної компетентності виступає посилення його якостей як майбутнього фахівця. Професійній компетентності властива повна реалізація здібностей і цінностей людини як професіонала, виявлення і розвиток своїх творчих можливостей, пізнання ним своєї власної природи і прагнення стати тим, ким він може і хоче стати. Це свідомий, цілеспрямований процес розкриття особистістю своєї власної активності та індивідуальності, реалізація власних зусиль, розвиток особистісних та професійних якостей в обраній професії (Філімонова, 2016). Саме здатність до творчості є однією з найбільш важливих умов для успішного самовираження особистості, її всебічної самореалізації та адаптації в сучасному світі.

Щоб знайти належне місце в суспільстві, майбутній інженерпедагог харчової галузі повинен: гнучко адаптуватися в змінних життєвих ситуаціях, самостійно набувати необхідних знань, уміти застосовувати їх на практиці для розв'язання різних проблем з метою знаходження "свого місця" протягом усього життя; самостійно критично мислити, вміти побачити труднощі, які виникають у реальному світі, і відшукати шляхи їх раціонального подолання; чітко усвідомлювати, де і яким чином знання, якими він володіє, можуть бути використані в навколишній дійсності; бути здатним генерувати нові ідеї, творчо мислити; грамотно працювати 3 інформацією (вміти збирати необхідні для дослідження певної задачі факти, аналізувати їх, висувати гіпотези щодо розв'язання проблем, робити необхідні узагальнення, порівняння 3 аналогічними або альтернативними варіантами, встановлювати статистичні закономірності, формулювати аргументовані висновки і на їх основі виявляти й розв'язувати нові проблеми); бути готовим до конструювання й творчого оформлення власних інноваційних ідей у вибраній професійній сфері; бути організатором складної, напруженої діяльності щодо вирішення творчих фахових завдань; володіти глибокими та міцними знаннями, професійним мисленням, багатомірною свідомістю, здатністю до самовизначення в навколишній дійсності, у системі міжособистісних відносин; бути комунікабельним, контактним у різних соціальних групах, вміти одночасно працювати у різних галузях, передбачати конфліктні ситуації або уміло виходити з них; самостійно працювати над розвитком власної моральності, інтелекту, культурного рівня; мати власну професійно-особистісну та соціокультурну позицію.

Майбутні фахівці харчової галузі повинні добре розуміти, що для їх самоствердження і самореалізації у житті потрібні знання, практичні й інтелектуальні вміння. Ті якості особистості, які виділяються роботодавцями, економістами, практичними працівниками освіти, формуються саме у процесі творчої професійної діяльності. Творчі здібності нині все більше цінуються в усіх галузях життя (Вдовенко, 2015). 
Тому створення умов для розвитку творчої професійної діяльності особистості - одне з найважливіших завдань вищої освіти.

Висновок. На основі процесуального та особистісного підходів до вивчення категорії творчості виявлено, що це діяльність, яка заснована на реорганізації наявного досвіду та формуванні нових комбінацій знань, умінь та навичок особистості. Найбільш ефективним механізмом творчого професійного розвитку майбутніх інженерів-педагогів харчової галузі має статися, по-перше, вироблення умінь самостійно поповнювати і творчо застосовувати набуті знання в різних практичних і педагогічних ситуаціях, по-друге, - формування особистості із свідомим ставленням до виконання функціональних обов'язків, високими фаховими компетентностями та професійно-педагогічними якостями, здатними до саморозвитку і самореалізації. Перспективи подальших досліджень пов'язуємо з дослідом сутності творчої професійної діяльності інженерівпедагогів та вимогами до ії реалізації в умовах закладів професійнотехнічної освіти.

\section{Література}

1.Батюшков Ф. Творчество: энциклопедический словарь Брокгауза и Эфрона / Ф. Батюшков. - СпБ.: Издательское дело, 1901. - Т. 64. - С 729.

2.Бехтерев В.М. Первоначальная эволюция детского творчества в объективном изучении / В.М. Бехтерев. - СпБ.: Издательское дело, 1910. - 50 с.

3. Біла І.М. Психологія дитячої творчості / І.М. Біла. - К.: Фенікс, 2014. - 137 с.

4.Білієнко Л.Б. Розвиток педагогічної творчості вчителів у системі внутрішкільної методичної роботи: автореф. дис. на здобуття наук. ступеня канд. пед. наук: 13.00.01 / Л.Б. Білієнко/ Київський ун-т ім. Т.Г. Шевченка. - К., 1994. - 20 с.

5.Білобровко Т.І. Практичний розум як передумова педагогічної творчості: автореф. дис. на здобуття наук. ступеня канд. фрілос. наук: 09.00.03 / Т.І. Білобровко / Київський ун-т ім. Т.Г. Шевченка. - К., 1996. - 24 с.

6.Бодалев А.А. Психологические проблемы смысла жизни / А.А. Бодалев // Вопросы психологии. - 1995. - №4. - С. 147-150.

7.Вдовенко О.І. Проблеми формування творчих здібностей майбутніх кваліфікованих робітників харчової промисловості / О.І. Вдовенко // Молодий вчений. - Квітень 2015. - №4 (19). - Частина 3. - С. 18-21.

8.Герлянд Т. Сучасні аспекти формування професійної компетентності майбутніх кваліфікованих робітників / Т. Герлянд // Педагогіка і психологія професійної освіти: науково-методичний журнал. - 2010. - № 1-2. - С. 37-43.

9.Гончаренко С.У. Український педагогічний словник / С.У. Гончаренко. К.: Либідь, 1997. - 374 с.

10. Даниленко Л.І. Формування та розвиток творчого потенціалу педколективу / Л.І. Даниленко // Рідна школа. - 1996. - №10. - С. 28-32.

11. Дубова Н., Харитонова В. Формування професійної компетентності майбутніх інженерів-педагогів харчової галузі в процесі практичної підготовки / Н. Дубова, В. Харитонова // Проблеми підготовки сучасного вчителя. - 2018. № 18. - С 167-174.

12. Калошина И.П. Структура и механизмы творческой деятельности: нормативный подход / И.П. Калошина. - Москва: Изд-во МГУ, 1983. - 168 с.

13. Кривильова О.А. Підготовка майбутніх учителів до творчої діяльності: монографія / О.А. Кривильова. - Донецьк: ТОВ «Юго-Восток, Лтд», 2008. - 200 с.

14. Обухова Н.П. Развитие творчества студентов как педагогическая проблема в вузах США: автореф. дис. на получение науч. степени канд. пед. наук. 
- Казань, 1990. - 17 с.

15. Поташник М.М. Педагогическое творчество: проблемы развития и опыт: пособие для учителя / М.М. Поташник. - К.: Радянська школа, 1988. - 187 с.

16. Романчук Н.О. Модель особистості майбутнього інженера-педагога / Н.О. Романчук // Вісник аграрної науки Причорномор'я. - 2006. - Випуск 4. C. 303-307.

17. Філімонова І.А. Проблеми професійної підготовки майбутніх фрахівцівтехнологів у вищих педагогічних навчальних закладах / І.А. Філімонова // Сучасні інформаційні технології та інноваційні методики навчання у підготовці фахівців: методологія, теорія, досвід, проблеми: зб. наук. пр. / редкол. Київ-Вінниця: ТОВ фірма «Планер». - 2016. - Випуск 47. - С.284-287.

18. Renzulli J., Reis S., Smith L. The Revolving-Door Model: A New Way of Identifying the Gifted / J. Renzulli, S. Reis, L. Smith // Phi Delta Kappah. - 1981. - N62. - P. 648-649.

\section{References}

1.Batyushkov, F. (1901). Tvorchestvo: entsiklopedicheskiy slovar' Brokgauza $i$ Efrona. SpB.: Izdatel'skoye delo. [in Russian].

2.Bekhterev, V.M. (1910). Pervonachal'naya evolyutsiya detskogo tvorchestva $v$ ob"yektivnom izuchenii. SpB.: Izdatel'skoye delo. [in Russian].

3.Bila, I.M. (2014). Psihologiya dityachoï tvorchosti. [in Ukrainian].

4.Bilienko, L.B. (1994). Rozvitok pedagogichnoï tvorchosti vchiteliv u sistemi vnutrishkilnoï metodichnoï roboti [Development of pedagogical creativity of teachers in the system of in-school methodical work] (Extended abstract of Candidate's thesis). K. [in Ukrainian].

5.Bilobrovko, T.I. (1996). Praktichnii rozum yak peredumova pedagogichnoï tvorchosti [Practical reason as a prerequisite for pedagogical creativity] (Extended abstract of Candidate's thesis). K. [in Ukrainian].

6.Bodalev, A.A. (1995). Psihologicheskie problemi smisla jizni. Voprosi psihologii - Psychology issues, 4, 147-150. [in Russian].

7.Vdovenko, O.I. (2015). Problemi formuvannya tvorchih zdibnostei maibutnih kvalifikovanih robitnikiv harchovoï promislovosti. Molodii vchenii - Young scientist, 4 (19), (3), 18-21. [in Ukrainian].

8.Gerlyand, T. (2010). Suchasni aspekti formuvannya profesiinoï kompetentnosti maibutnih kvalifikovanih robitnikiv. Pedagogika i psihologiya profesiinoï osviti: naukovo-metodichnii jurnal - Pedagogy and psychology of vocational education: a scientific and methodological journal, 1-2, 37-43. [in Ukrainian]. Ukrainian].

9.Goncharenko, S.U. (1997). Ukraïnskii pedagogichnii slovnik. K.: Libid. [in

10. Danilenko, L.I. (1996). Formuvannya ta rozvitok tvorchogo potencialu pedkolektivu. Ridna shkola - Home school, 10, 28-32. [in Ukrainian].

11. Dubova, N., \& Haritonova, V. (2018). Formuvannya profesiinoï kompetentnosti maibutnih injeneriv-pedagogiv harchovoï galuzi $\vee$ procesi praktichnoï pidgotovki. Problemi pidgotovki suchasnogo vchitelya - Problems of preparation of the modern teacher, 18, 167-174. [in Ukrainian].

12. Kaloshina, I.P. (1983). Struktura $i$ mehanizmi tvorcheskoi deyatelnostinormativnii podhod. Moskva: Izd-vo MGU. [in Russian].

13. Krivilova, O.A. (2008). Pidgotovka maibutnih uchiteliv do tvorchoï diyalnosti: monografiya. Doneck: TOV "Yugo-Vostok, Ltd". [in Ukrainian].

14. Obuhova, N.P. (1990). Razvitie tvorchestva studentov kak pedagogicheskaya problema $v$ vuzah SShA [Development of students' creativity as a pedagogical problem in US universities] (Extended abstract of Candidate's thesis). Kazan. [in Russian]. 
15. Potashnik, M.M. (1988). Pedagogicheskoe tvorchestvo: problemi razvitiya $i$ opit: posobie dlya uchitelya. K.: Radyanska shkola. [in Russian].

16. Romanchuk, N.O. (2006). Model osobistosti maibutnogo injenerapedagoga. Visnik agrarnoï nauki Prichornomor'ya - Bulletin of Agrarian Science of the Black Sea, (4), 303-307. [in Ukrainian].

17. Filimonova, I.A. (2016). Problemi profesiinoï pidgotovki maibutnih fahivciv_tehnologiv u vischih pedagogichnih navchalnih zakladah. Suchasni informaciini tehnologiï ta innovaciini metodiki navchannya u pidgotovci fahivciv: metodologiya, teoriya, dosvid, problemi: zb. nauk. pr. - Modern information technologies and innovative teaching methods in the training of specialists: methodology, theory, experience, problems: Coll. Sciences. ave., (47), 284-287. [in Ukrainian].

18. Renzulli, J., Reis S., \& Smith L. (1981). The Revolving_Door Model_A New Way of Identifying the Gifted. Phi Delta Kappah, 62, 648-649. [in English].

\begin{abstract}
АНОТАЦІЯ
Стаття присвячена теоретичному обгрунтуванню творчого складника профресійного розвитку інженерів-педагогів харчової галузі.

Сучасні соціально-економічні умови відкривають нові напрями до розробки, створення $і$ впровадження в практику перспективних моделей підготовки компетентних фрахівців, а саме інженерів-педагогів. Вони мають поєднувати профресійні знання та вмінн, з майстерністю здійснювати навчання фахівців, здатних до творчої праці, професійного саморозвитку, вдосконалення, які можуть вчасно адаптуватися в мінливих умовах ринку. Серед таких слід відмітити інженерів-педагогів харчової галузі, підготовка яких зосереджується на оволодінні ними цілісною системою професійних знань, умінь, навичок, досвідом творчої профресійної діяльності, формуванні готовності до вирішення виробничих творчих завдань, проявленні творчого потенціалу, інтелектуальних i духовно-моральних здібностей. За своєю природою творчість вимагає оригінальності, вміння відмовлятися від стереотипів діяльності, знань, хоча без таких стереотипів, як бази, воно неможливе. Тому професійна особистість повинна, з одного боку, мати набір стандартизованих знань, умінь $і$ навичок, а 3 іншого - можливість і вміння відмовлятися від них у пошуках інших знань $i$ способів діяльності, більш правильних для ситуації. В цей момент відбувається творче перетворення людиною дійсності, ї подальщий розвиток. Майбутні інженери-педагоги харчової галузі потребують мотивування до продуктивної, творчої профресійної діяльності. Творчість стає вагомим засобом навчальнопізнавальної та науково-дослідної діяльності студентів.
\end{abstract}

Ключові слова: творчість, творча діяльність, інженер-педагог, інженерпедагог харчової галузі, профресійна компетентність. 